The author says that it is not the chief business of the school to impart information, but "to inspire the pupil with the joy of creation." This worthy end is to be attained, how? "First, the best general means of cultivating all classes of minds in their artistic milieu is, of course, the study of art history." Shades of Ruskin, these are the author's own italics!

Perhaps the author's method will best explain the ponderous inconclusiveness of this inartistic book. At the head of an undigested bibliography he says:

Each student has, or may have, his own individual way of following up the scent of a subject. In my own case, this is to read everything I can lay my hands upon from all quarters, not noting down at first what I read, but gradually clarifying my mind by reflection in the light of my own slowly evolved convictions. Hence, the list of books that follows is partial, not complete.

Why use valuable space in reviewing such a book? To recommend to Professor Ladd, Dr. Davies, and all Ph.D.'s the extension of the methods of Froebel and Montessori in the schools. Goethe said, "Fortunate is he who at an early age knows what art is."

Boston, Mass.

Charles Zueblin

Peace and War in Europe. By Gilbert SLATER, D.Sc., Principal of Ruskin College. Oxford, London: Constable \& Co., I915. Pp. vi+r22.

This is among the sanest of the books produced on the present European war. Its author, Dr. Slater, principal of Ruskin College, Oxford, is one of the rising thinkers of the newer British sociological school, which is headed by such men as Professor Geddes and Professor Hobhouse. It discusses with frankness and impartiality the causes of the war, the possible terms of peace, and the problem of the future maintenance of peace. The discussion rises above the ordinary type because of its frequent reference to general sociological principles.

While the point of view of the book is confessedly British, yet there is a frankness in the statement of fact which we do not always find in similar works. A single passage will serve to illustrate this. Dr. Slater says:

We have to confess that in ordinary times the average Briton, Frenchman, or Russian is a slacker compared with the average German. . . . . Germany should make us ashamed of the extent to which we allow private interest to 
override those of the Commonwealth, and the quarrels of factions to imperil the general safety.

Perhaps the best chapter is the last, in which Dr. Slater discusses the problem of the future maintenance of peace. He points out here the necessity above all of creating an international morality much higher than past history has known in Western civilization. He says:

Our own record for the past sixty years includes the Crimean War, Chinese opium wars, Afghan and Zulu wars, bombardment of Alexandria, the Soudan War, the South African War. There are, of course, varying opinions about each of these; there is one, but only one, of them which I personally should be prepared to defend before an international audience. Nor has our inaction been much more honorable than our action.

But the nations will learn, Dr. Slater concludes, as a result of the terrible experiences of the present war. British "navalism"-the right of capture of private goods at sea-as well as German militarism will have to be given up; and society as a whole will win the right to control its belligerent organs.

UNIVERSITY OF MISSOURI

Charles A. Ellwood

\section{British Rural Life and Labor. By Francis George Heath.}

London: P. S. King \& Son, I9I I. Pp. xi+3I8. Ios. $6 d$.

This volume deals exclusively with that class of rural inhabitants of Great Britain who work for an employer. The author suggests that the terms "servant" and "peasant" are fit designations of the class of paid assistants. The work is largely a detailed statement of the conditions of employment as seen in classes of workers, terms of employment, various modes of payment, wages, housing, clothing, and food, for the various counties and districts of England, Wales, Scotland, and Ireland. Part V gives a comparative glimpse of the situation in the four parts of the Kingdom, and Part VI, which is an appendix, describes the conditions which obtained in $\mathrm{I} 873$, and is intended to afford a basis of comparison with the present situation. Twenty tables, most of which deal with wages, make it possible to compare the various counties and parts of the Kingdom in the matter of the items covered.

Since it is impossible to review the details of the work in a brief space, attention will be directed to some of the more important results established.

Relative to wages, it is apparent that there has been a general advance between 1873 and I90I, the latter date being the latest date 